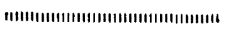

解 説

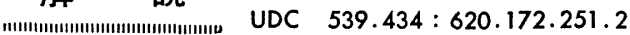

\title{
金属材料技術研究所におけるクリープデータ
}

シート作成の現状

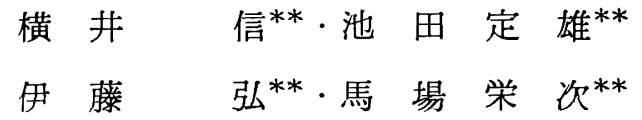

\section{Current Status of NRIM Creep Data Sheet Project}

\author{
Shin Yokol, Sadao IKedA, Hiroshi Ito, and Eiji BABA
}

1.はじめに

わが国で製造されている各種の高温用金属材料を対象 に, 高温短時間引張り, クリープ, およびクリープ破断 試験などの材料試験を，中立的な立場で行い，機械的性 質に関する基準的データを求め，かつ広く公表すること によつて, これら材料の適正な使用と高温機器の安全珄 の確保に寄与することを目的に，金属材料技術研究所 （以下，金材技研之略す）か，国産高温用金属材料のク リープデータシート作成に着手してから 15 年になる. この間, クリープデータシート作成業務は, 日本鉄鋼協 会・クリープ委員会〔委員長 : 田村今男 (京大教授)〕お よび同委員会に属する金材技研クリープデータシート連 絡分科会〔主查 : 田中良平 (東工大教授)〕の積極的な 支援のもとに進められており，後述のように，数多くの 試験材料をサンプリングし，データシートも版を重ねる までに至つた.

金材技研におけるクリープデータシートについては， 既に紹介されているが(1)2), 最近, 数万時間のクリープ破 断データを含む増補改訂版も10 種類を数え, また溶接 継手に関する試験にも着手したので，クリープデータシ 一トの幅広い利用と内容への批判を仰きたく，現状を報 告する.

\section{2. 試験の種類と方法}

クリープデータシート作成のために, 化学分析, 結晶 粒度, 硬さ, 顕微鏡組織, 室温および高温引張, ならび にクリープおよびクリープ破断などの各試験を行つてい る.これらの試験方法およびそのための温度管理, なら びにクリープ破断試験の手順について, 以下簡単に述へ る.

\section{1 化学分析}

クリープデータシートの化学分析表には，原則とし て，各材料製造者から提出されたミルシートに記載され ている製品分析值を転記している. 同一仕様材で分析値 に欠測值のある元素などに関しては，金材技研で行つた 化学分析結果を記載している.

金材技研においては，各試験材料について，まず分光 分析により微量成分の定性分析を行い，不純物元素の有 無とおおよその量を確認したのち, 高温性質に影響を及 ぽすと思われる元素について定量分析を実施している.

\section{$2 \cdot 2$ 結晶粒度}

結晶粒度測定方法は，鋼のオーステナイト結晶粒度試 験方法（JIS G 0551）に基ついて実施している. 結晶粒 度現出方法は, オーステナイト系試験材料は固溶化熱処 理法, フェライト系試験材料は酸化法で行い, 温度, 保 持時間は試験材料のミルシートに記載された熱処理履歴 に基つきき決定している.

各視野の粒度判定には, 接眼レンズに粒度板を使用し て行い, 視野数は最低 20 視野とし, 各視野の判定結果 から平均粒度番号を算出している。

\section{$2 \cdot 3$ 硬 さ}

硬さの測定方法は, ロックウェル硬さ試験方法 (JIS Z 2245）により実施している。ロックウェル $\mathrm{C}$ および B 硬 さのいずれを用いるかは, 試験材料の種類や熱処理履歴 などを考虑して決定している．硬さ測定用試料は，原則 としてクリープ試験片の平行部に相当する部分から採取 し, 測定面は試験荷重方向に垂直な面である. 測定回数 は, 試料 1 個につき 5 点とし, その平均値を表示してい る.

\section{4 顕铰鏡組雜}

各試験材料の組織観察は, 材料受入れ時に光学影微鏡 により実施している、試料の採取位置などは硬さの場合

* 昭和 54 年 7 月 2 日受付 (Received July 2, 1979) (依頼解説)

** 金属材料技術研究所 (National Research Institute for Metals, 2-3-12 Nakameguro Meguro-ku 153) 
と同様で，検鏡面は試験荷重方向に平行な面である.

写真撮影は, 100, 200, および 400 倍で行つている. データシートには, 増補改訂版から, 原則として 1 種類 の試験材料につき，製造者ごとに 1 チャージを選び， 100 および 400 倍の組織写真を掲載している.

\section{5 窒温および高温引張試験}

鉄鋼材料の高温引張試験方法（JIS G 0567）に基づい て試験を実施している. 試験片は, 後述のクリープ試験 片と同一形状寸法の試験片群のなかから無作為に抽出し ている. 標点間のひずみ速度は, 室温, 高温とも, 約 $1 \%$ の伸びを生ずるまで $0.3 \% / \mathrm{min}$, その後破断に至るまで は $7.5 \% / \mathrm{min}$ である.

試験温度範囲は, 室温からクリープ破断試験の最高温 度, またはそれより $50^{\circ} \mathrm{C}$ 高い温度までで, 温度間隔は クリープ破断試験温度範囲は $50^{\circ} \mathrm{C}$, その他は $100^{\circ} \mathrm{C}$

\section{である。}

\section{6 クリープおよびクリープ破断試験}

金属材料の引張クリープ試験方法（JIS Z 2271）およ び金属材料の引張クリープ破断試験方法（JIS Z 2272) に基づいて試験を実施している. 試験片の寸法は，平行 部直径 6 または $10 \mathrm{~mm}$ で, 標点距離は直径の 5 倍であ

表 1 クリープデータシート作成に使用している クリープ試験機の機種と台数

\begin{tabular}{c|c|r|r|r}
\hline 形 式 & $\begin{array}{c}\text { 荷重容量 } \\
(\mathrm{kgf})\end{array}$ & $\begin{array}{c}\text { 最高温度 } \\
\left({ }^{\circ} \mathrm{C}\right)\end{array}$ & 台 数 & \multicolumn{2}{|c}{$\begin{array}{c}\text { 試験片 } \\
\text { 本 }\end{array}$} \\
\hline & 5000 & 800 & 9 & 9 \\
& 3000 & 800 & 134 & 134 \\
& 3000 & 1000 & 26 & 26 \\
& 1500 & 800 & 176 & 176 \\
単 式 & 1500 & 1050 & 33 & 33 \\
& 750 & 800 & 48 & 48 \\
& 750 & 1050 & 18 & 18 \\
& 300 & 1100 & 69 & 69 \\
\hline 単式小計 & & & 513 & 513 \\
\hline 複 式 & 1500 & 800 & 124 & 2232 \\
18-本吊 & 1500 & & \\
\hline 合 計 & & & 637 & 2745 \\
\hline
\end{tabular}

表 2 クリープ試験温度制御範囲の目標值

\begin{tabular}{|c|c|c|c|}
\hline \multirow{2}{*}{$\begin{array}{c}\text { 試験温度 } \\
\left({ }^{\circ} \mathrm{C}\right)\end{array}$} & \multicolumn{2}{|c|}{ 温度制御範囲の目標値 } & \multirow{2}{*}{$\begin{array}{l}\text { JIS } \\
\text { 許容範国 } \\
\left({ }^{\circ} \mathrm{C}\right)\end{array}$} \\
\hline & $(\mu \mathrm{V})$ & $\left({ }^{\circ} \mathrm{C}\right)$ & \\
\hline $\begin{array}{l}450 \text { 以下 } \\
451 \sim 600\end{array}$ & $\begin{array}{l} \pm 15 \\
\pm 16\end{array}$ & $\begin{array}{l} \pm 1.4 \\
\pm 1.4\end{array}$ & \pm 3 \\
\hline $\begin{array}{l}601 \sim 640 \\
641 \sim 800\end{array}$ & $\begin{array}{l} \pm 22 \\
\pm 24\end{array}$ & $\begin{array}{l} \pm 1.9 \\
\pm 2.0\end{array}$ & \pm 4 \\
\hline $\begin{array}{l}801 \sim 870 \\
871 \sim 1070 \\
1071 \text { 以上 }\end{array}$ & $\begin{array}{l} \pm 36 \\
\pm 39 \\
\pm 42\end{array}$ & $\begin{array}{l} \pm 2.9 \\
\pm 2.9 \\
\pm 3.1\end{array}$ & $\begin{array}{l} \pm 6 \\
\text { たたし } \\
1000^{\circ} \mathrm{C} \text { 以下 }\end{array}$ \\
\hline
\end{tabular}

る. 平行部表面はペーパー仕上げで，その粗さはおおよ そ $\mathrm{H}_{\mathrm{max}}=0.4 \sim 0.5 \mu \mathrm{m}, \mathrm{H}_{\mathrm{rms}}=0.08 \sim 0.12 \mu \mathrm{m}$ であ る. 試験片はその軸方向が, 板, 棒, 管については圧延 方向または軸方向と, ロータやディスクにおいては半径 方向と一致するように採取している.

使用しているクリープ試験機の機種と台数は, 特殊な ものを除き，表 1 に示すとおりであり,荷重精度は \pm 0.5 \%以内である.

試験片の温度变動は, 自動制御と温度設定目盛の修正 により表 2 に示す温度制御範囲の目標値, すなわち, JIS の規定値の $1 / 2$ に押えている.

クリープ伸びの測定には，つば付試験片を用い，それ に取付けた伸び計でダイヤルゲージ（JIS 合格品）の指 示值を読み取る方式である. 目標試験時間が 3 万時間以 内の場合は最小目盛 $0.01 \mathrm{~mm}$ のダイヤルゲージを, そ れ以上の長時間試験には $0.001 \mathrm{~mm}$ のものを使用して いる.

\section{$2 \cdot 7$ 温度管理}

$2 \cdot 7 \cdot 1$ 標準のトレーサビリティ (traceability)

クリープ試験温度の管理に使用する 標準白金熱電対 (PR10, PR13) のトレーサビリティは, 図 1 に示す経路 を経て国家標準につながつている.

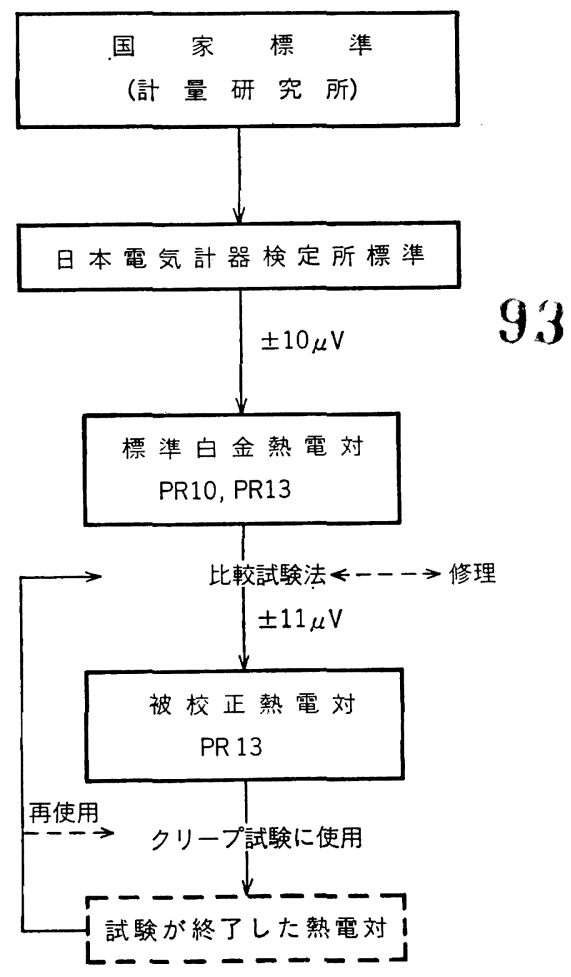

困 1. 標準のトレーサビリティ 


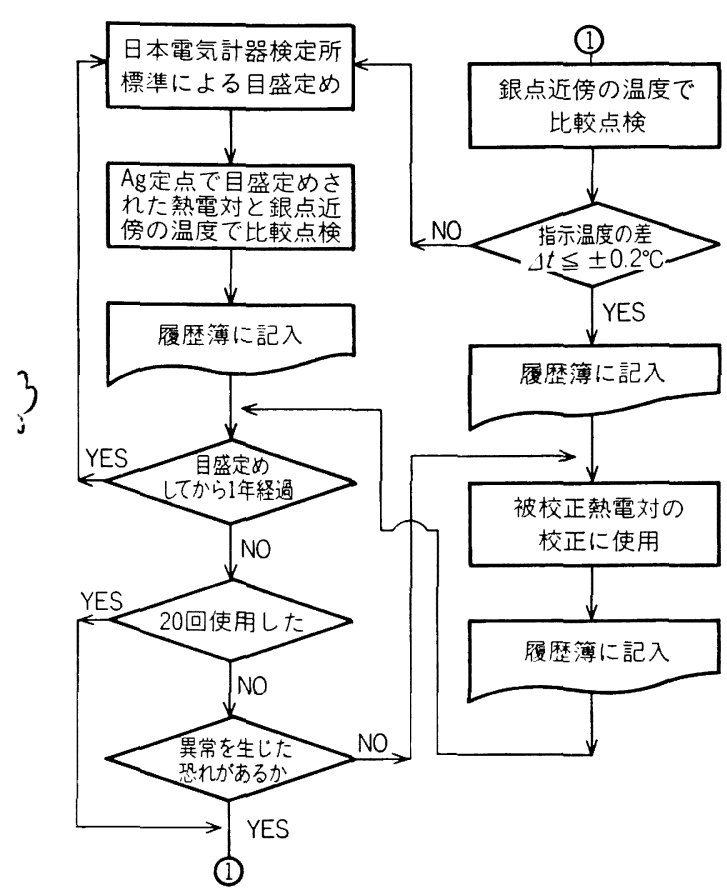

図 2. 標準熱電対の管理図

\section{$2 \cdot 7 \cdot 2$ 標準熱電対の管理}

標準熱電対は図 $2^{3)}$ に示すような管理図に基ついて管 理している.

\section{$2 \cdot 7 \cdot 3$ 熱電対の珄能}

標準の熱電対 (PR10, PR13) およびクリープ試験に 使用する熱電対 (PR13, 以下使用熱電対と略す) の品 質扎よび特性は，1968 年国際実用温度目盛）（以下 IPTS-68 と略す)および JIS5) を十分に満足し，使用熱 電対においては, 熱起電力の許容差を JIS ${ }^{5)}$ の約 $1 / 2$ に 押えている.

$2 \cdot 7.4$ 校正装置およびクリープ試験温度の測定装圆. 校正装置は, 単式クリープ試験機の加熱炉と同一形式 の比較校正炉と JIS6) A 級測定方式に規定された测定機 器により構成されている。

クリープ試験温度は，1 日 2 回，クリーブ試験温度監 視装置により, 湘定, 記録し, それ以外は常時温度記録 計で記録している.

これら装置の結線方式と測定機器の公称精度を図 3 に 示す.

\section{$2 \cdot 7 \cdot 5$ 校正方法}

適当な前処理を施した熱電対を, 日本電気計器検定所 に依頼し， $\pm 10 \mu \mathrm{V}$ の精度で $100^{\circ} \mathrm{C}$ から $50^{\circ} \mathrm{C}$ きさ に $1100^{\circ} \mathrm{C}$ まで目盛りづけしたものを標準とし,ほぼ土 $1^{\circ} \mathrm{C}$ の精度で比較法により, $0.05^{\circ} \mathrm{C} / 2 \mathrm{~min}$ の安定した 状態で，使用熱電対の校正を行つている，標準および測
（標準熱電対側）

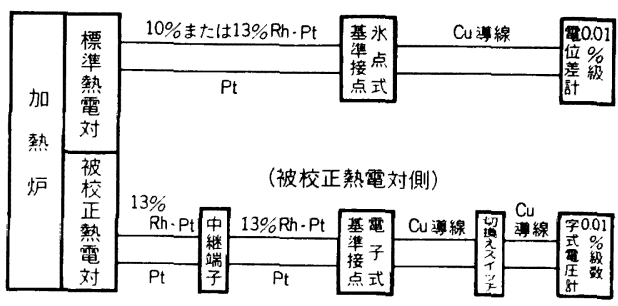

熱電対の比較法による校正方式 94

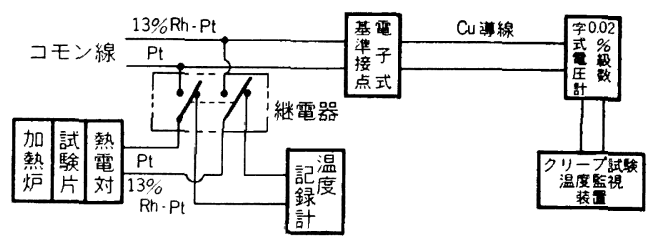

クリープ試験片の温度測定方式

因 3. 校正および測定装置

表 3 標準および測定機器の校正周期とその精度

\begin{tabular}{|c|c|c|c|}
\hline & 測定範囲 & 校正周期 & 校正精度 \\
\hline $\begin{array}{l}\text { 標準熱電対 } \\
\\
\text { 標準電池 } \\
\text { (エアパス } \\
\text { り) }\end{array}$ & $\begin{array}{l}0 \sim 1100^{\circ} \mathrm{C} \\
1.01817 \mathrm{~V} \\
\left(\text { 約 } 30^{\circ} \mathrm{C}\right)\end{array}$ & $\mid$\begin{tabular}{c|c}
1 年むたは経 \\
時変化が 0.2 \\
${ }^{\circ} \mathrm{C}$ を超えた \\
とき \\
\\
\multicolumn{2}{c|}{1 年 }
\end{tabular} & $\begin{array}{l} \pm 10 \mu \mathrm{V} \\
\pm 10 \mu \mathrm{V}\end{array}$ \\
\hline $\begin{array}{l}\text { 電 位 差 計 } \\
\text { 数字式電压計 } \\
\text { 数字式電圧計 }\end{array}$ & $\begin{array}{l}10 \mathrm{mV} \\
10 \mathrm{mV} \\
10 \mathrm{mV}\end{array}$ & $\begin{array}{ll}1 & \text { 年 } \\
1 & \text { 年 } \\
1 & \text { 年 }\end{array}$ & $\begin{array}{l} \pm 2 \mu \mathrm{V} \\
\pm 1.2 \mu \mathrm{V} \text { 以内 } \\
\pm 1.6 \mu \mathrm{V} \text { 以内 }\end{array}$ \\
\hline
\end{tabular}

[佻考]

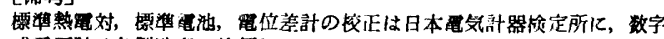
式㫣压䂥は各造者に依頼している。

定機器の校正周期とその精度を表 3 に示す.

なお，現在有効な温度目盛は IPTS-68 であるが，こ の目盛りに改訂される前に試験に着手した試験材料の試 験に使用する熱電対については，IPTS-48（60 年修正 版）目盛りを使用し，トレーサビリティに一一貫性をもた せている.

\section{8 クリープ破断試験の手順}

クリープデータシートを作成するための試験の手順な どについては，英国規格でを参考に，前記の金材技研ク リープデータシート連絡分科会で検討し，クリープ委員 会で承認されたクリープデータシート作成作業暫定方案 に準拠している.

最長試験時間は, 米国機戌学会 (ASME) のボイラ・ 圧力容器コードに 規定されている許容応力値 の算出根 拠8) に基づいて，火力や原子力発電設備に関係する材料 
は 10 万時間を目標としたが，化学工業やガスタービン 関係は 3 万時間を超えるデータを得ることを一応の目標 とした. そして当初は, 前記暫定方案に基づき, 1 種類 の材料について各製造者からそれぞれ 3 チャージずつサ ンプリングした試験材料に対し，100，300，1000，お よび 3000 時間目標の試験をそれぞれ行つた後, 同一製 造者の 3 チャージのうちの 2 チャージについて 1 万およ び 3 万時間目標の試験を行い, 次にそのらちの 1 チャー ジについて 5〜10 万時間目標の試験を行らことにして いた.しかし，クリープ破断性質はばらつきが大きく， しかも 1 万時間を超えるあたりから特徵的な挙動を示す
場合もあるので，実際には，原則として，すべての試験 材料について各最長目標時間までの試験を行つている.

クリープ伸びの測定は，単式試験機による 3000 時間 以上を目標とした試験のときに行つている.さらに, 10 万時間で $1 \%$ のクリープひずみを生ずる応力を求める ために, 数種の材料について, 1 種類につき 1 チャーシ を選択して行つている.

なお，クリープおよびクリープ破断試験の温度は，試 験材料が実際に使用される場合に，最も問題になると思 われる温度を含む範囲で， $50^{\circ} \mathrm{C}$ または $100^{\circ} \mathrm{C}$ 間隔に 3 から 5 水準としている。

表 4 試 験 材 料

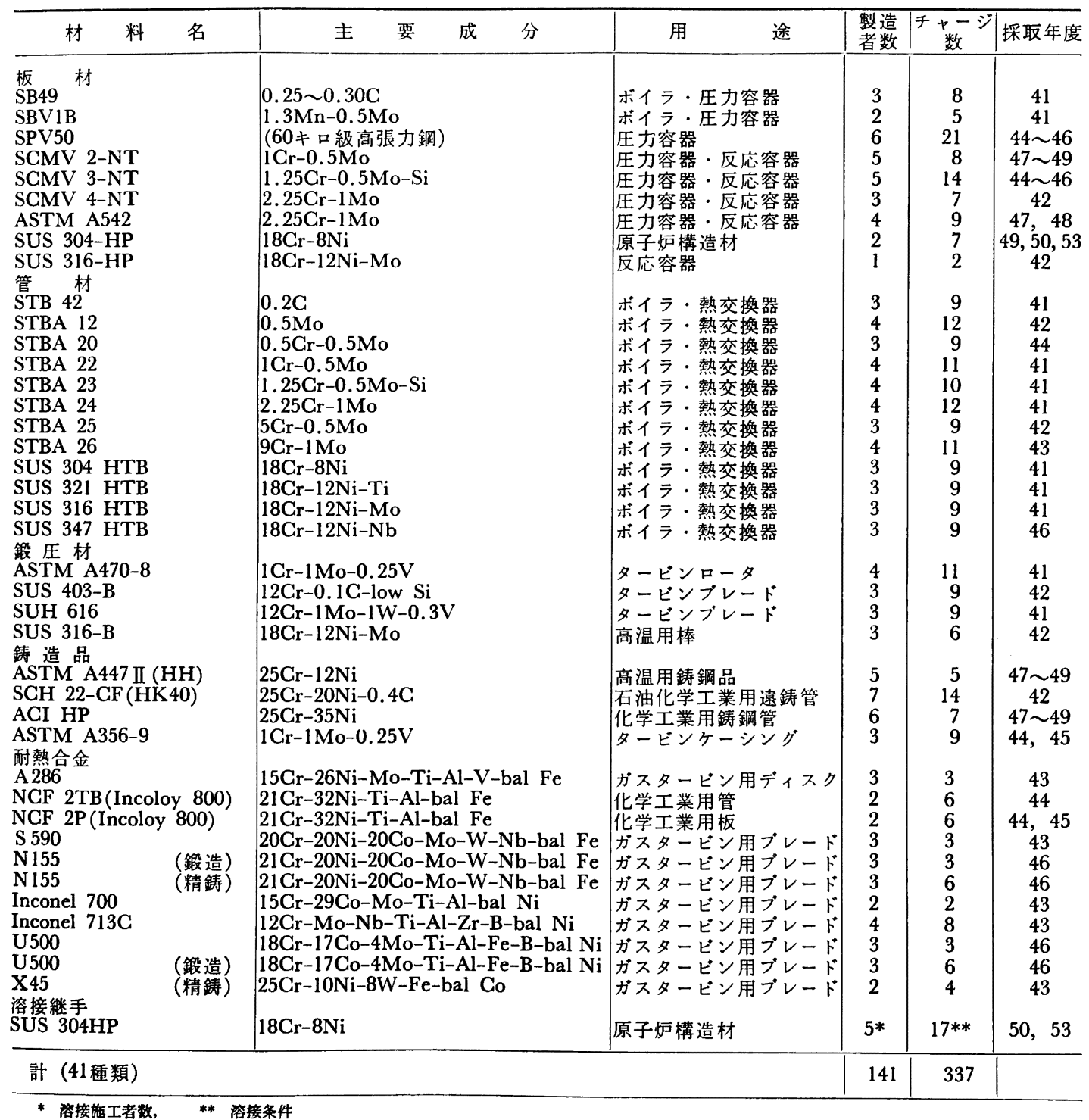




\section{3. 試 験 材 料}

\section{$3 \cdot 1$ 試験材料のサンプリング}

クリープデータシート作成のために，表 4 に示す 41 種類, 337 チャージの試験材料を, 延べ 141 社の材料 製造者からサンプリングして，試験を行つている。これ らの試験材料は，表 5 および 6 に示すような選択基準お よび手続きによりサンプリングした。なお，これらの試 験材料の製造者および溶接施工者は表 7 に示すとおりで ある。

\section{$3 \cdot 2$ 溶接継手}

溶接構造物においては，溶接継手の高温機械的性質が 重要であることはいらまでもない。しかし溶接継手のク リープ破断強さは, 図 49 ) に示す上うに, 溶接施工条件 によつて大きく影響される。 したがつて，少なくとも標 準的な溶接施工方法が確立されていればよいか，現状で はそのようなものがないので，基準的で普遍性のあるデ 一タを求めるデータシートに, 溶接継手を取入れにくか つた. しかし最近, IIW (International Institute of Welding）でも溶接継手のクリープ（破断）性質を問題 にしており 10)，また高速增殖炉や高温ガス炬，あるいは

表 5 試験材料の選択基準

\footnotetext{
1. 国産材料であること

2. 原則として市販材のこと

3. 2 社以上で製造されていること （特定の特許材でないこと）

4. 製造実績のあること

5. 事業用火力発電, 原子力発電, 化学工業, 石油 化学工業, ガスタービンなどの高温装置・機器 用材料として，一般に使用されている標準的な 材料(規格材)のこと

6. 近い将来使用され，かつ重要と思われる材料て あること （開発途中の材料は除く）
}

表 6 試験材料のサンプリングの手続き

クリープ委員会・金材技研クリープデータシート連絡分 科会において

1. 新たに試験すべき材料の検討

2. アンケートなどによる調查

3、材料製造者之使用者を交えた審議

4. 試験候補材料（試験条件，材料製造者，材料仕 様なども含む）の希望決定

5. 金材技研に対し新しい試験材料の要望 金材技研において，

6. 試験材料の検討 · 決定

7. 試験材料の仕様决定 （この間，上記分科会，材料製造者と打合せ）

8. 発注

9. サンプリング（試験材料の購入）
表 7 試験材料の製造者および溶接施工者

\begin{tabular}{|c|c|c|}
\hline 石川島播磨重工業(株) & & 川䐀重工業(株) \\
\hline 川崎製鉄 (株) & & 久保田鉄工（株） \\
\hline (株) 栗本鉄工所 & & (株) 神戸製鋼所 \\
\hline (株)小松製作所 & & 新日本製鉄（株） \\
\hline 住友金属工業(株) & & 大同製鋼 $($ 株)* \\
\hline 太平金属工業（株） & & 大平洋金属（株） \\
\hline 特殊製鋼(株)* & & 日本金属工業（株） \\
\hline 日本鋼管（株） & & 日本高級金属（株） \\
\hline 日本ステンレス(株) & & （株）日本製鋼所 \\
\hline 日本特殊鋼 (株)* & & 日本治金工業（株） \\
\hline 日立金属 (株) & & (株) 日立製作所 \\
\hline 富士製鉄 (株)** & & 三菱金属 (株) \\
\hline 三菱重工業(株) & & 三菱製鋼 (株) \\
\hline \multicolumn{3}{|l|}{ 八幡製鉄 $($ 株)** } \\
\hline & . & 現 大同特殊鋼 (株) \\
\hline & $* *$ & 現 新日本製鉄 (株) \\
\hline
\end{tabular}

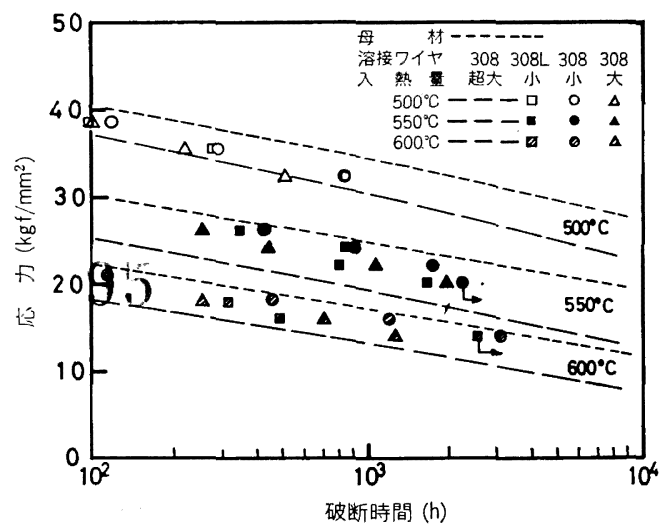

図 4. SUS 304 溶接継手のクリープ破断強さ

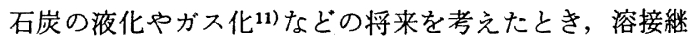
手は重要な位置を占めると思われるので，最も標準的な 材料といらことで，SUS $304 \mathrm{HP}$ を母材とする溶接継 手の試験に，1975 年から着手した.この試験計画（溶接 条件）は表 8 に示すとおりである。

\section{3 試験材料の種類と JIS 材料規格との関係}

今までにサンプリングした試験材料を JIS に規定さ れている高温用材料との対比でみると, 発電用火力技術 基準や圧力容器の構造 (JIS B 8243) の設計許容引張応 力表に記载されクリープ領域のデータが必要な材料は, 28 規格, 152 種類に対し, 該当する本試験材料は 22 種 類，すなわち $14.5 \%$ にしかすぎない.

\section{4. 試験の進行状況}

\section{$4 \cdot 1$ 試験材料}

クリープ破断試験の進行状況を表 9 に示す. 試験の進 行に差があるのは，試験材料をサンプリングした年度， 
表 8 SUS 304 鋼のサブマージアーク溶接条件

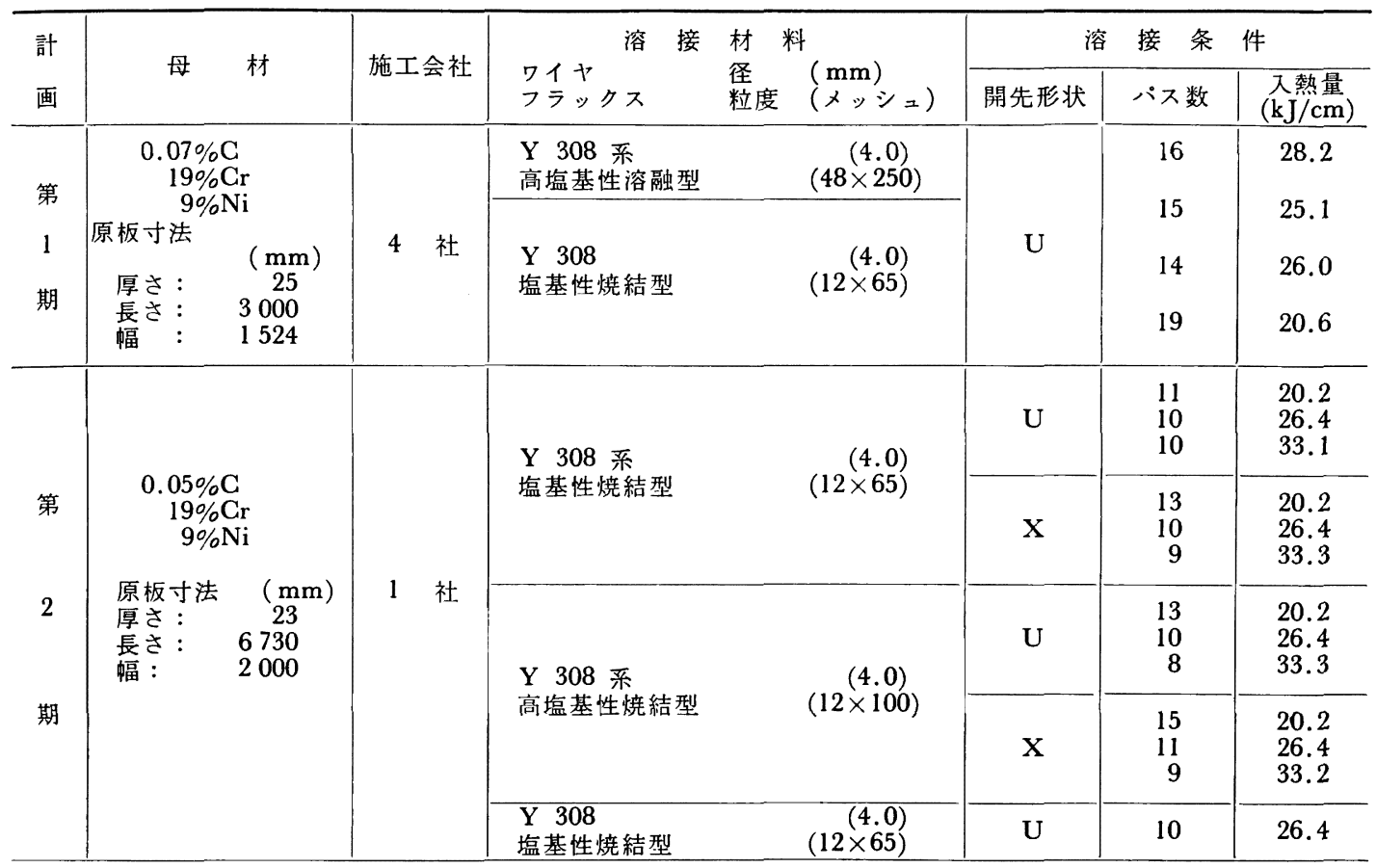

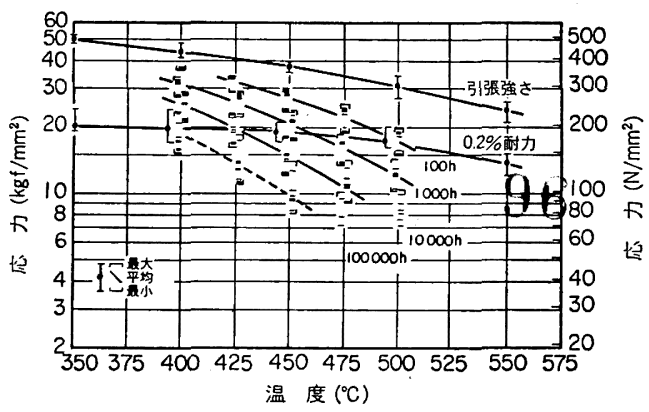

図 5. STB 42 の $0.2 \%$ 耐力, 引張強さ, および Orr-Sherby-Dorn バラメータ法で求めたク リープ破断強さ

長時間試験応力の設定の難易さ，使用可能な試験機（試 験温度と荷重容量）の数による制約などのためである.

10 万時間破断目標の試験に初めて着手したのは管材 6 鋼種（STBA 22，23，24，および SUS 304，321，316 HTB) を対象に，金材技研創立 13 周年記念日の 1969 年7月 1 日であり，既に 10 年 $(87648 \mathrm{~h})$ を経過す る.これらの試験材料のらち, 一部のチャージについて は，7〜8万時間で破断したものも多い，予測が大きく はずれたものについては, 長時間試験応力を適宜に見直 して，試験の追加や中止をしている.

なお, 試験材料についての製品分析, 硬さ, オーステ
ナイト結晶粒度, および引張試験は, 一部を除いてすへ て完了している. 受入材に対する光学顕微鏡による組織 検査は一応済んでいるが，電子顕微鏡による組織観察 は, クリープ破断後の試験片に対する系統的な調査も含 め, 今後データシートの一部として発表していく予定で ある。

\section{2 溶接継手}

SUS $304 \mathrm{HP}$ を母材とする溶接継手に関する試験の ち，第 1 期計画については，すでに 1 万時間目標の試 験に着手している. 第 2 期計画は, 所定の溶接施工を完 了し，これから試験片の切出しと加工を行う段階であ る.

\section{5. 試 験 テーータ}

\section{$5 \cdot 1$ 金材技研クリープテータシートの内容と送付先}

サンプリングした各試験材料について行つた試験の結 果は，材料の種類ごとに表と図にまとめ，金材技研クリ ープデータシート (英文) として随時発表している. そ の共通的な内容は, 表 1 亿試験材料の 製造履歴の詳細 (溶解炉, 鋼塊重量, 脱酸条件, 製品形状, 寸法, 製造法 と熱処理履歴，オーステナイト結晶粒度，および硬さ)， 表 2 に化学分析値, 表 3 と図 1 に引張性質を見開きで, 表 4 にクリープ破断性質, 図 2 に破断時間と応力, 図 3 に破断時間と伸びおよび絞りの関係をそれぞれ示してい る.な扰, 增補改訂版（材料の種類の違いを示す各巻番 
表 9 クリーブ破断試験進行状況

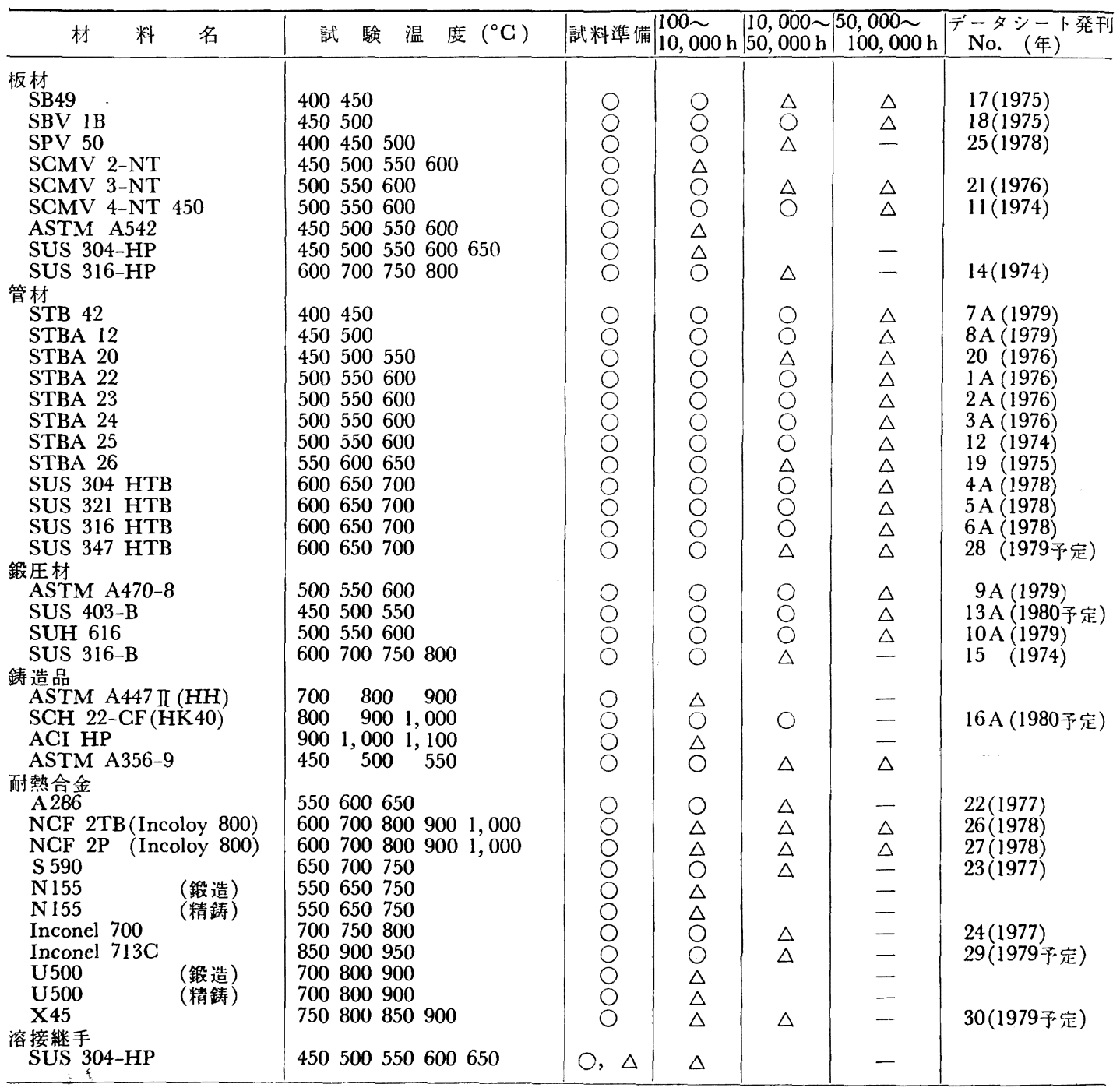

注：○完了, $\triangle$ 進行中

号の数字のあとに，第 1 回改訂版にはAを付けている.) では, 表 5 に 10 万時間破断応力の推定 值, 図 4 飞而 力, 引張強さ，抢よび $100 ， 1000,10000,100000$ 時 間の破断強さを応力と温度の関係で示すとともに, 図 5 に 100 打よび 400 倍の光学顕锟鏡組織写真を揭載して いる.

これらのデータシートは，金属材料の高温特性に関す る情報との交換を原則的な条件に，国内約 160 ヶ所,国 外約 180 ヶ所 $(32$ ヶ国) の大学，研究機関，拈よび関 連企業などに送付している。

\section{$5 \cdot 2$ 試験データ}

データシートとして既に発表した 27 種類の材料に関 するデータの数量を表 10 に示す. 引張りとクリープ破 断試験片の合計は 6288 本, 延破断時間は 3570 年間に なる. 特に, 3 万〜 7 万時間のデータを含む增補改訂版 の No. 1A〜No. 10A は, 長時間データの多いことを反 映して 1 本当たりの平均破断時間は 10894 時間である.

クリープデータシートとして発表したこれら試験材料 のクリープ破断性質などについては，既に依田によつて 紹介されている12)ので，ここでは増補改訂を行つた 10 種類の材料についてのデータの一例を示すに止める. 增 
表 10 クリーブデータシートに記載されている試験片本数と試験時間

\begin{tabular}{|c|c|c|c|c|c|c|c|c|}
\hline \multirow{2}{*}{$\begin{array}{l}\text { データ } \\
\text { シート } \\
\text { No. }\end{array}$} & \multirow{2}{*}{ 材 } & \multirow{2}{*}{ 名 } & \multirow{2}{*}{ チャージ数 } & \multicolumn{2}{|c|}{ 高温引張試験 } & \multicolumn{3}{|c|}{ クリープ破断試験 } \\
\hline & & & & 温度水準 & 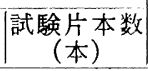 & 温度水準 & 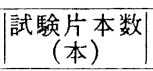 & $\begin{array}{c}\text { 延試験時間 } \\
\left(\times 10^{3} \mathrm{~h}\right)\end{array}$ \\
\hline $1 \mathrm{~A}$ & $1 \mathrm{Cr}-0.5 \mathrm{Mo}$ & $(\mathrm{T})$ & 11 & 10 & 110 & 4 & 213 & 1,912 \\
\hline $2 \mathrm{~A}$ & $1.25 \mathrm{Cr}-0.5 \mathrm{Mo}-\mathrm{Si}$ & ( T) & 10 & 10 & 100 & 4 & 197 & 1,476 \\
\hline $3 \mathrm{~A}$ & $2.25 \mathrm{Cr}-1 \mathrm{Mo}$ & ( $\mathrm{T}$ ) & 12 & 10 & 120 & 4 & 217 & 1,946 \\
\hline $4 \mathrm{~A}$ & $18 \mathrm{Cr}-8 \mathrm{Ni}$ & ( $\mathrm{T}$ ) & 9 & 11 & 99 & 4 & 192 & 2,543 \\
\hline $5 \mathrm{~A}$ & $18 \mathrm{Cr}-8 \mathrm{Ni}-\mathrm{Ti}$ & $(\mathrm{T})$ & 9 & 11 & 99 & 4 & 193 & 2,235 \\
\hline $6 \mathrm{~A}$ & $18 \mathrm{Cr}-12 \mathrm{Ni}-\mathrm{Mo}$ & $(\mathrm{T})$ & 9 & 11 & 99 & 4 & 208 & 2,704 \\
\hline $7 \mathrm{~A}$ & $0.2 \mathrm{C}$ & $(\mathrm{T})$ & 9 & 9 & 81 & 3 & 143 & 1,580 \\
\hline $8 \mathrm{~A}$ & $0.5 \mathrm{Mo}$ & ( $\mathrm{T})$ & 12 & 9 & 108 & 3 & 182 & 2,067 \\
\hline $9 \mathrm{~A}$ & $1 \mathrm{Cr}-1 \mathrm{Mo}-0.25 \mathrm{~V}$ & $(\mathrm{~F})$ & 9 & 10 & 90 & 4 & 182 & 2,217 \\
\hline $10 \mathrm{~A}$ & $12 \mathrm{Cr}-1 \mathrm{Mo}-1 \mathrm{~W}-0.3 \mathrm{~V}$ & (B) & 9 & 10 & 90 & 4 & 215 & 2,476 \\
\hline 11 & $2.25 \mathrm{Cr}-1 \mathrm{Mo}$ & (P) & 6 & 10 & 60 & 4 & 106 & 675 \\
\hline 12 & $5 \mathrm{Cr}-0.5 \mathrm{Mo}$ & ( $\mathrm{T})$ & 9 & 11 & 99 & 4 & 159 & 975 \\
\hline 13 & $12 \mathrm{Cr}$ & (B) & 9 & 9 & 81 & 4 & 170 & 930 \\
\hline 14 & $18 \mathrm{Cr}-12 \mathrm{Ni}-\mathrm{Mo}$ & (P) & 2 & 10 & 20 & 4 & 36 & 192 \\
\hline 15 & $18 \mathrm{Cr}-12 \mathrm{Ni}-\mathrm{Mo}$ & (B) & 6 & 10 & 60 & 4 & 111 & 510 \\
\hline 16 & $25 \mathrm{Cr}-20 \mathrm{Ni}-0.4 \mathrm{C}$ & $(\mathbf{C T})$ & 14 & 6 & 84 & 5 & 194 & 751 \\
\hline 17 & $0.3 \mathrm{G}$ & (P) & 8 & 9 & 72 & 3 & 90 & 581 \\
\hline 18 & $1.3 \mathrm{Mn}-0.5 \mathrm{Mo}$ & (P) & 5 & 10 & 50 & 3 & 61 & 265 \\
\hline 19 & $9 \mathrm{Cr}-1 \mathrm{Mo}$ & ( $\mathrm{T})$ & 11 & 10 & 110 & 4 & 227 & 1,035 \\
\hline 20 & $0.5 \mathrm{Cr}-0.5 \mathrm{Mo}$ & (T) & 9 & 9 & 81 & 4 & 147 & 623 \\
\hline 21 & $1.25 \mathrm{Cr}-0.5 \mathrm{Mo}-\mathrm{Si}$ & (P) & 13 & 10 & 130 & 4 & 214 & 1,002 \\
\hline 22 & A 286 & (D) & 2 & 11 & 22 & 4 & 45 & 256 \\
\hline 23 & S 590 & (B) & 3 & 12 & 36 & 4 & 65 & 336 \\
\hline 24 & Inconel 700 & (B) & 2 & 12 & 24 & 4 & 41 & 152 \\
\hline 25 & 60 キ口級高張力鋼 & (P) & 21 & 10 & 210 & 4 & 279 & $\mathrm{I}, 449$ \\
\hline 26 & Incoloy 800 & $(\mathrm{~T})$ & 6 & 11 & 66 & 4 & 68 & 165 \\
\hline 27 & Incoloy 800 & (P) & 6 & 11 & 66 & 3 & 66 & 234 \\
\hline 計 & & & 231 & - & 2,267 & - & 4.021 & $\begin{array}{c}31,287 \\
(3,570 \text { 年間) }\end{array}$ \\
\hline
\end{tabular}

注： $\mathrm{T}:$ 管, $\mathrm{F}$ : 鍛造品, $\mathrm{B}:$ 棒, $\mathrm{P}:$ 板, D : ディスク, CT: 鋳造管

補改訂版では先に述べたように，10 万時間を含む各時 間に打ける破断強さの推定*を行つている. それを結果 の一例として図 $5 \sim 14$ に示す。これらの図から，炭素 鋼, Mo 鋼, $\mathrm{Cr}-\mathrm{Mo}$ 鋼, $\mathrm{Cr}-\mathrm{Mo}-\mathrm{V}$ 鋼, $12 \mathrm{Cr}$ 系鋼, 18-8 系鋼之材料が変わるに従い, 温度に対する各時間強 さはもちろん, 曲線の形状や温度依存性などが, 耐力や 引張強さとの関連も含め, 微妙に変わつていくことがわ かる.

さらに，推定した 10 万時間破断強さと規定の許容応 力値とを比較すると，図 15 および 16 に示すよらに, これらの試験材料が，現行の安全率 (10 万時間クリー プ破断強さの平均值に対し 1.67 , 最小值に対し 1.25) を满足しない場合のあることがわかる.

また近く増補改訂を予定している HK 40 についての

* 推定に用いた外插方法の各式わよび回攸式は, 次のとおりである（据 細は文献 24)〜26) を参照されたい).

Larson-Miller : $P=(T+273.15)(C+\log t)$

Orr-Sherby-Dorn : $P=\log t-Q / 2.303 R(T+273.15)$

Manson-Haferd : $P=\left(\log t-\log t_{\mathrm{a}}\right) /\left((T+273.15)-T_{\mathrm{a}}\right\}$

Manson-Brown : $P=\left(\log t-\log t_{\mathrm{a}}\right) /\left\{(T+273.15)-T_{\mathrm{a}}\right\}^{r}$

回噜式: $P=b_{0}+b_{1} \log \sigma+b_{2} \log \sigma^{2}+\cdots \cdots+b_{\mathbf{k}} \log \sigma^{\mathbf{k}}$

ととに,

$t:$ 破断時間 $(\mathrm{h}), T:$ 渭度 $\left({ }^{\circ} \mathrm{C}\right), \sigma:$ 応力 $\left(\mathrm{kgf} / \mathrm{mm}^{2}\right)$,

$\mathrm{C}, Q, t_{\mathrm{a}}, T_{\mathrm{a}}, \quad r:$ 最適パラメー夕定数, $R$ : ガス定数,

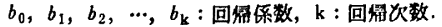

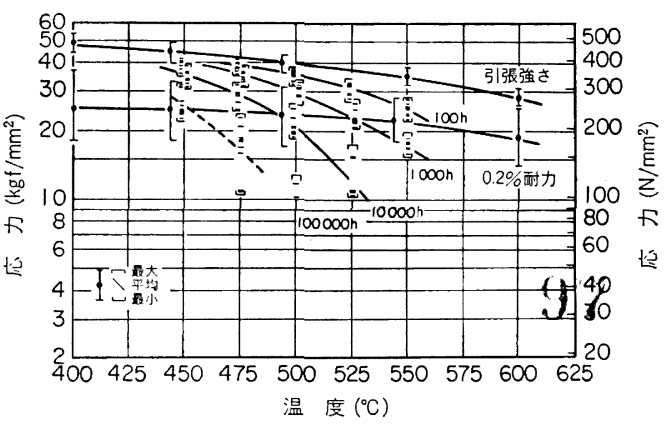

図 6. STBA 12 の $0.2 \%$ 耐力, 引張強さ, および Manson-Haferd パラメータ法で求めたクリ 一プ破断強さ

Larson-Miller 法による整理結果を図 17 に示す。この 図から高温長時間側で，EsTRUCH ら ${ }^{13)}$ は央際よりも強 めを推定していたことがわかる。

\section{6. 金材技研クリープデータシートの 利用と問題点}

\section{6 -1 熱処理条件}

試験材料は，耐熱合金の精密鋳造材などを除き，すべ 


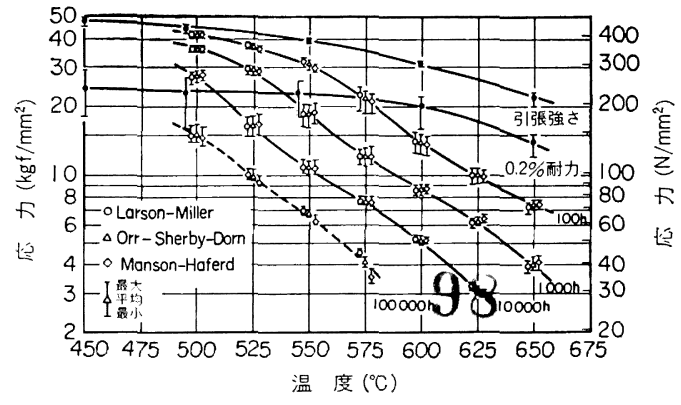

図 7. STBA 22 の $0.2 \%$ 耐力, 引張強さ,および 各ハララメータ法で求めたクリープ破断強さ

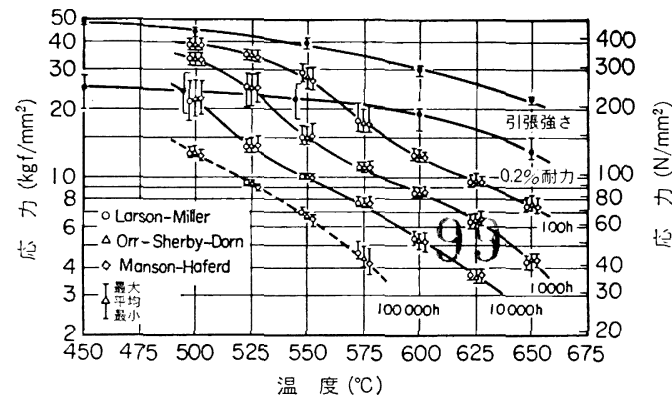

図 8. STBA 23 の $0.2 \%$ 耐力, 引張強さ, および 各バラメータ法で求めたクリープ破断強さ

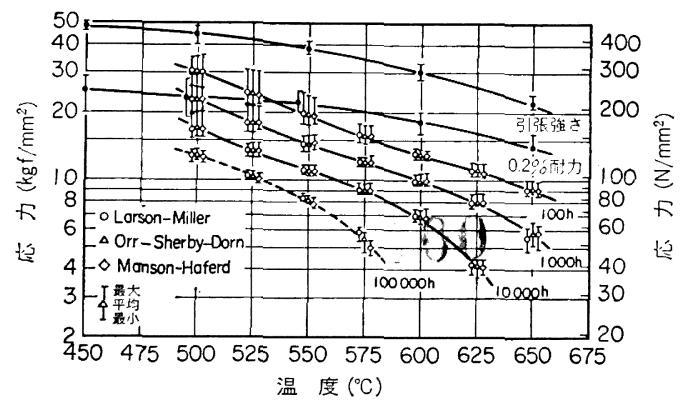

図 9. STBA 24 の $0.2 \%$ 耐力, 引張強さ, および 各パラメータ法で求めたクリープ破断強さ

て実機に使用予定の管，板，棒などの中から無作為に抽 出, または口ータやディスクなどの実体から切り出すこ とを原則としているので, 各試験で求めたデータは, 実 機で使用されている材料の性質を代表するもの之確信し ている. したがつて，これらの試験データから，設計に 必要な許容応力值を算出，または見直しすることは極め て有意なことであり，このクリープデータシート作成の 最大の目的の一つがそこにあることはいらまでもない。 しかし，これらの試験データを，製造履歷との関連で調 べる場合, 特に熱処理条件との関係を求める場合, 問題 を生ずる. といらのは, 数值的に表示された熱処理条件

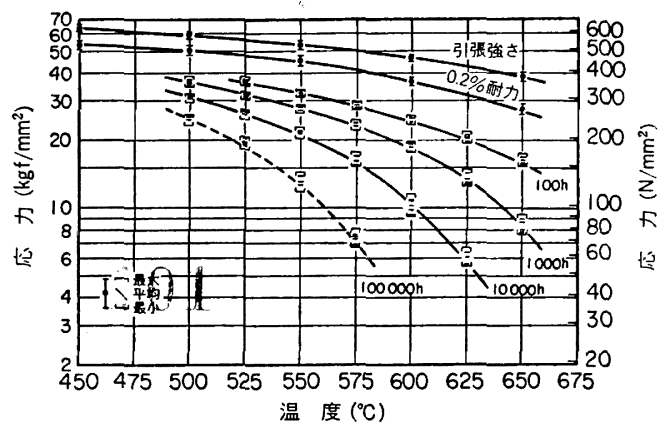

図 10.1Cr-1Mo-0.25V 鋼（ターピンロータ材）の $0.2 \%$ 耐力, 引張強さ，および MansonHaferd パラメータ法で求めたクリープ破断 強さ

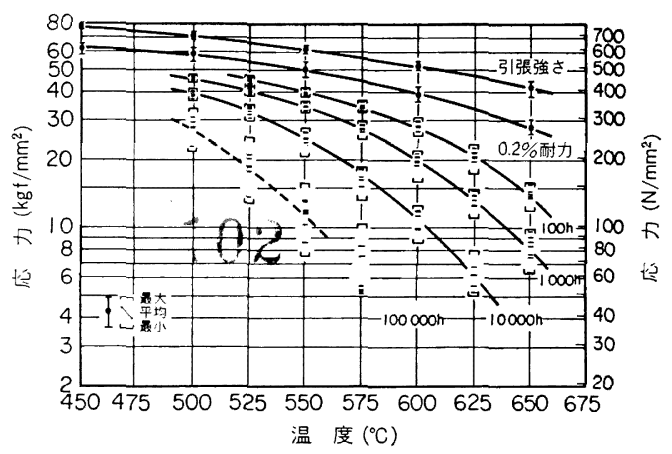

因 11. 12Cr-1Mo- $1 \mathrm{~W}-0.3 \mathrm{~V}$ 鋼の $0.2 \%$ 耐力, 引 張強さ，および Manson-Brown パラメータ 法で求めたクリープ破断強さ

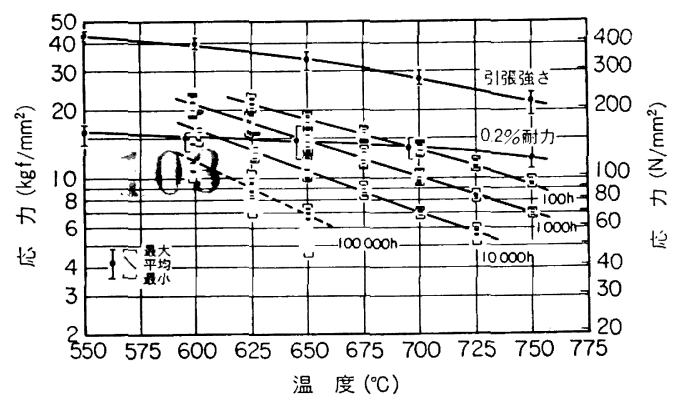

図 12. SUS $304 \mathrm{HTB}$ の $0.2 \%$ 耐力，引張強さ，お よび Manson-Brown パラメータ法で求めた クリープ破断強さ

は, ミルシートに記載された製造工程上の管理目標值の よらなものが多く, 実験室的に管理され, かつ測定され たものでないからである. そのことは, 熱処理条件と結 晶粒度や硬さなどとの関係に扣ける矛盾からも推察され る.

\section{2 不純物の影響}

クリープ性質は, 周知のように組織敏感な性質である 


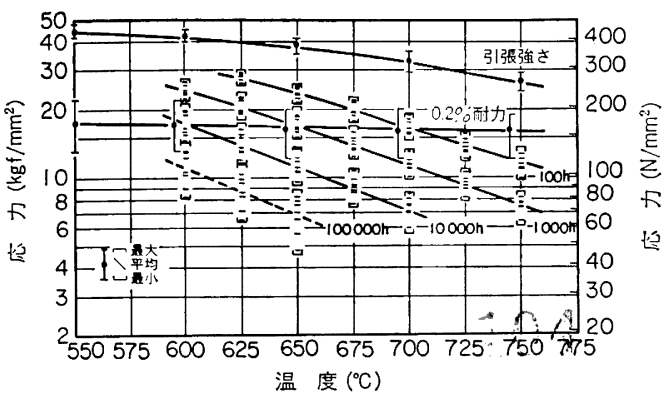

図 13. SUS 321 HTB の $0.2 \%$ 耐力, 引張強さ，お よび Manson-Brown パラメータ法で求めた クリープ破断強さ

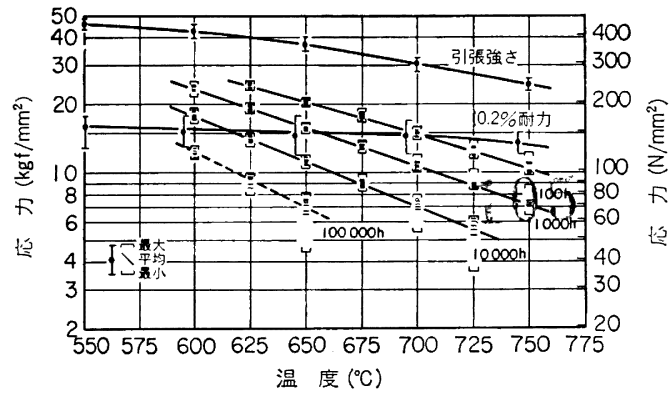

図 14. SUS 316 HTB の $0.2 \%$ 耐力, 引張強さ，お よび Manson-Brown パラメータ法で求めた クリーブ破断強さ

から，熱処理や成分に大きく影響される．しかし，材料 規格（JIS）に扣いて，不純物の制限規定は皆無に等し い. そのためか，本試験材料の場合も，同一規格材と称 しながら, 微量元素の有無やその含有量が大きく異なつ ているものがあつた，そのため，試験データもチャージ 間で大きなばらつきを示していた，したがつて，これら の試験データを使つて, 各材料のクリープ破断強さを評 価する場合には, 熱処理条件はもちろんのこと, 脱酸条 件や不純物（例えぱ，炭素鋼における Mo や 18-8 鋼

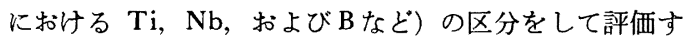
る必要がある。

一方, 最近の設計思想の特徵は, 強さ制限のみでな く，ひずみ制限を考虑するようになつたことである。そ の意味からは，延性を評価する上に必要な情報として， 今後は, As, $\mathrm{Ce}, \mathrm{Sn}, \mathrm{Sb}, \mathrm{Te}, \mathrm{Tl}, \mathrm{Pb}, \mathrm{Bi}$ およびO などの微量元素714)15) の分析值も必要かもしれない.

\section{3 強さの評価方法}

耐力や引張強さについては，材料にもよるが，室温は もちろんのこと, 高温のデータもクリープに比べればは るかに多い，これらの評価方法を大別すると，（1）室 温の強さで基準化した傾向曲線による方法16)17)，(2) 温 度の関数として回㷌により求める方法, (3) 温度ごとに

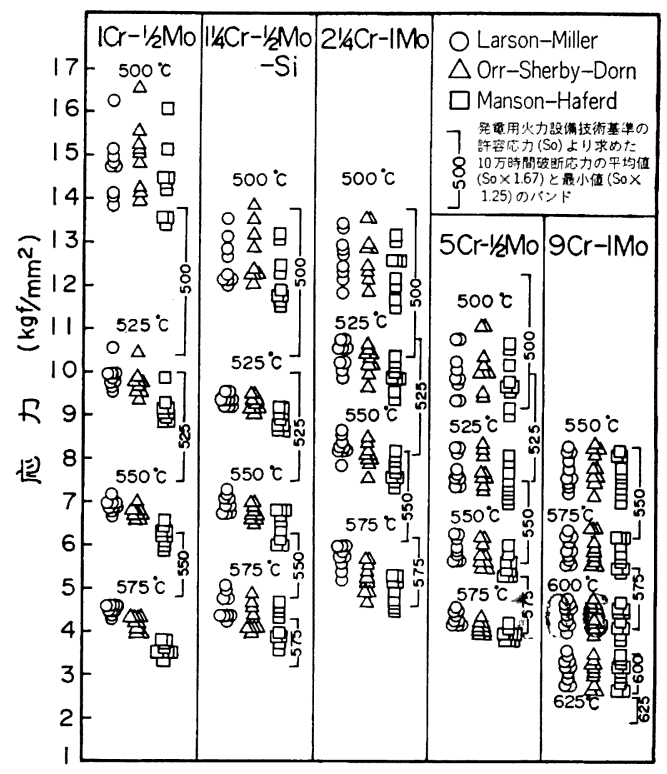

図 15. Cr-Mo 鋼の各パラメータ法で求めた 10 万 時間破断応力と許容応力との比較

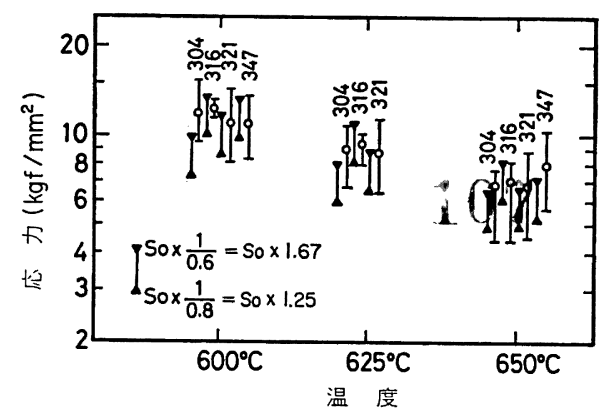

図 16. 18-8 系鋼の 10 万時間破断応力の推定值（最 大, 平均, 最小值) と許容応力 $\left(\mathrm{S}_{0}\right)$ との比 較

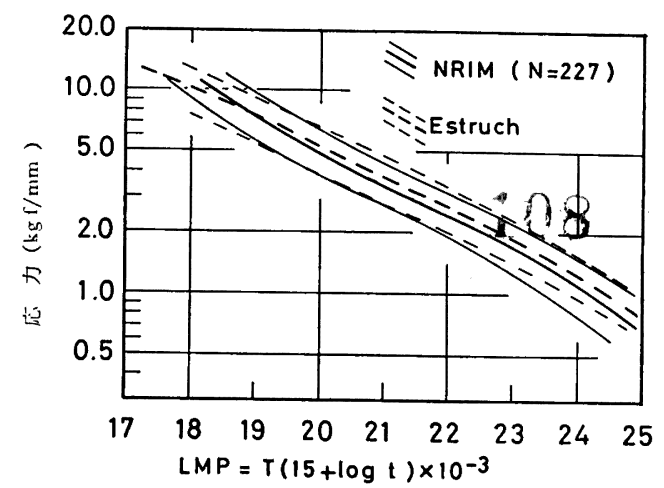

図 17. HK 40 のクリープ破断強さ 
室温の強さの関数として回㷌により求める方法17)18) とな

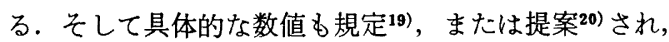
解説 ${ }^{21)}$ もり，国際的比較22) むなされている.わが国で む, 降伏強さ值 “ $S_{\mathrm{y}}$ ” と引張強さ值 “ $S_{\mathrm{u}}$ ” の数値を発 電用原子力技術基準 ${ }^{23}$ に規定するために，本データシー トをはじめとする国内データの整理解析をもとに日本鉄 鋼協会とステンレス協会からそれぞれ提出された原案に ついて，日本電気協会ならびに通商産業省で検討が進め られているとのことである.

な技，データシートに記載した引張データのらち，室 温の規定值をわずかにはずれているものもあるが、これ は, 室温の引張試験を高温の試験方法に準処して行つた ことと, 試験片の採取位置や形状によるためで, 納入時 の素材に対する試験データは，すべて規格值を満足して いるものである.

さて一方，クリープ強さやクリープ破断強さについて は，有効な長時間データが少なく，かつそれぞれの時間 に対する強さは，試験データからなんらかの方法で推定 しなければ求まらない数值である. 金材技研クリープデ 一タシートでは，前述のように各時間強さの推定を，既 に報告24) 26) した手順に基づいて，Larson-Miller ${ }^{27) ， ~}$ Orr-Sherby-Dorn'28), Manson-Haferd ${ }^{29)}$, および Manson-Brown ${ }^{30)}$ ，の各パラィータ法で行つており，データ の区分けや重み付けなどの処理は施していない.一つの チャージについての同一試験データでも，外挿の方法や 計算の方法で違つた推定值を与えるが, 何を基準にして, ぞの数値を採用するかは，利用者の判断に委ねている.

材料の強さとしては, 現状では同一の規格に属するデ 一タの量や質の異なるチャージを一つの母集団として評 価しなければならず，チャージ数やデータ数の少ない上 に，ばらつきが比較的大きいので評価上問題も多いと思 5. しかし, ISO (International Organization for Standardization) では，既に各国からそれぞれ 1 万および 10 万時間の平均破断強さ值が提案され，ISO 規格に取り入 れるべく審議1731)が進められている段階である．この基 礎になる試験データとしては，アメリカは MPG (Metal Properties Council) ${ }^{32)}$, イギリスは BSCC (British Steelmakers Creep Committee) ${ }^{33)}$ ，西ドイッは VDEh (Verein Deutscher Eisenhüttenleute) ${ }^{34)}$, フランスは IRSID (Institut de Recherches de la Sidérurgie Française) ${ }^{35)}$ からそれぞれ出されているデータ集が，大 きく寄与しているものと思う.わが国としても，これら の動きに積極的に, 組織的に対処していく必要があろう.

\section{7.おわりに}

クリープデータシートの作成業務に関連して, データ

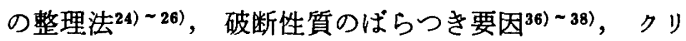
一プ試験前後の硬さや組織変化 ${ }^{39)}$-41)，扣よびクリープ 損傷42)などの研究も進めているが，ここでは最も主要な
研究試験業務であるクリープデータシート作成に絞つて 現状を報告した.

このプロジェクトのために, 1964 年から 1968 年に かけて, 約 14 億円の国家予算か建物などの施設や試験 設備として投入され, 以降, 若干の変動があつたが, 現 在, 直接経費として, 年間約 1700 万円の試験費と約 500 万 $\mathrm{kWh}$ の電力を使用し, 日々, 約 30 名の室員が従事 している.これらのことを考えるとき，このクリープデ ータシートが可能な限り最大限に活用されることを願わ ずにはいられない，多くの利用者にできるたけ役立つデ 一タを取得し, 提供していく心積もりである.

执わに，このクリープデータシート作成業務に対 し，常に，ご支援，ご指導いただいているクリープ委員 会金材技研クリープデータシート連絡分科会の田中良平 主査ならびに各委員に厚くお礼申し上げるととるに，こ の報告の機会を与えてくたさつた編集委員会に深く感謝 いたします。

\section{文献}

1) T. Kawada: Proc. of the 1971 International Conf. on Mechanical Behavior of Materials, III (1972), p. 142

2 ) 横井 信: 材料, 22 (1973) 234, p. 188

3 ) 横井 信: 計量管理, 22 (1973) 1, p. 14

$4)$ 計量研究所監修: 1968 年国際実用温度目盛, (1971)，【コロナ社]

5) JIS C 1 602: 熱電対

6) JIS Z 8704 : 温度の電気的測定方法

7 ) British Standard: Procedures for Obtaining Properties of Steel at Elevated Temperatures, B. S. 3228, Part 2 and 3, (1960)

8 ) ASME: Boiler and Pressure Vessel Code, Sec. I, (1977), p. 195

9) 金属材料技術研究所, 動力炬 - 核然料開発事業 団：高速実験灿構造材料のクリーブ試験に関する 研究, N241, 72-44 (1972)

10) IIW, Commission $X$-Working Group "Creep": DOC X-Creep-79/78, (1978)

11) Welding Research Council: Bulletin 241, (1978), p. 30

12) 依田連平：鉄と鋼，65（1979） 7, p. 725

13) $B$. Estruch and $C$. Lyth: Materials Technology in Steam Reforming Processes, ed. by C. Edeleanu, (1966), p. 29 [Pergamon Press]

14) H. R. TIPler: Conf. on Residuals, Additives, and Materials Properties, by Royal Society, National Physical Laboratory, and Metals Society, (1978)

15) G. B. Thomas and T. B. Gibbons: Metals Technol., 6 (1979) 3, p. 95

16) G.V. Smith: Reports of Current Work on Behavior of Materials at Elevated 
Temperatures, ed. by A. O. Schaefer, Publication G 87, (1974), p. 157 [ASME]

17) -1 International Standard: ISO $2605 / I$ and II $-1976(\mathrm{E})$.

17) -2 ISO/TC 17/SC 18: $181 \mathrm{E}$ (1977)

18) R. F. Johnson, J. Glen, M. J. May, H. G. Thurston, and $B$. H. Rose : HighTemperature Properties of Steels, ISI P 97 (1967), p. 62

19) ASME: Boiler and Pressure Vessel Code, Sec. III, Div. 1, Appendix I, (1977), p. 35 and p. 53

20) ISO/TC $17 / \mathrm{SC} 4$ : N808 E (1979)

21) 横井 信：圧力技術, 15 (1977) 5, p. 232

22) -1 V.K. SikKa and M. K. Booker: J. Pressure Vessel Technol., Trans. ASME, 99 (1977), p. 298

22)-2 C. R. Brinkman, $V . K$. SikKa, and $R . T$. King: Nuclear Technol., 33 (1977), p. 76

23）通商産業省：発電用原子力設備に関する構造等の 技術基準を定める告示，告示第 501 号，(1970)

24) 河田和美, 横井信, 田中千秋, 門馬義雄, 新谷 紀雄：鉄と鋼，56(1970)，p. 1034

25) 門馬義雄, 池田定雄, 馬場栄次, 宮崎昭光, 森下 弘, 横井 信: 学振耐熱金属材料第 123 委研究報 告, 18 (1977) 2, p. 149

26) 横井 信, 門馬義雄: 鉄と鋼, 65 (1979) 7, p. 831

27) F. R. LARSon and $J$. Miller: Trans. ASME, 74 (1952), p. 765

28) R. L. OrR, O. D. Sherby, and J.E. Dorn: Trans. ASM, 46 (1954), p. 113
29) S. S. MANSon and A. M. HAFErd: NACA, TN 2890, (1953)

30) S. S. MANson and $W . F$. Brown, Jr.: Proc. ASTM, 53 (1953), p. 693

31) ISO/DATA 1-1978 (E), Summary of Average Stress Rupture Properties of Wrought Steels for Boilers and Pressure Vessels, (1978)

32) ASTM Data Series, 例えば DS5, DS6 など

33) BSCC High-Temperature Data, (1973), [Iron and Steel Institute]

34) Ergebnisse deutscher Zeitstandversuche Langer Dauer, (1969), [VDEh]

35）文献 22)-1 より, Results of High-Temperature Creep Tests in French Steels, (1972), [IRSID]

36) 横井 信, 新谷紀雄, 郡宗幸, 田中秀雄: 材料, 25, (1976) 270, p. 249

37) 横井 信, 新谷紀雄, 郡 宗幸：材料, 26 (1977) 282, p. 241

38）横井信, 新谷紀雄, 田中秀雄: 学振耐熱金属材 料第 123 委研究報告, 15 (1974) 2. p. 113

39）横井信, 田中千秋, 門馬義雄, 伊藤弘：鉄と 鋼, 53 (1967) 11, p. 1245

40) N. Shin-ya, S. Yokol, and Y. Monma: Proc. of the 1971 International Conf. on Mechanical Behavior of Materials, III (1972), p. 87

41) Y. Monma, $S$. Yokoi, and $N$. Shin-ya: Proc. of the 1971 International Conf. on Mechanical Behavior of Materials, III (1972), p. 105

42) $N$. Shin-ya and $S$. $R$. Keown: Metal Sci., 13 (1979) 2, p. 89 